\title{
Front Matter: Volume 9614
}

, "Front Matter: Volume 9614," Proc. SPIE 9614, Laser Communication and Propagation through the Atmosphere and Oceans IV, 961401 (14 October 2015); doi: $10.1117 / 12.2218030$

EDent: SPIE Optical Engineering + Applications, 2015, San Diego, California, SPIE. United States 


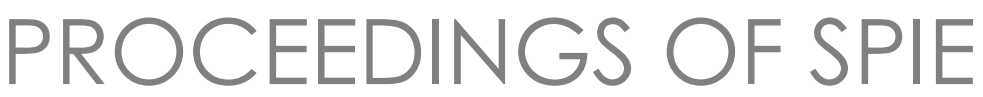

\title{
Laser Communication and Propagation through the Atmosphere and Oceans IV
}

\author{
Alexander M. J. van Eijk \\ Christopher C. Davis \\ Stephen M. Hammel \\ Editors
}

10-12 August 2015

San Diego, California, United States

Sponsored and Published by

SPIE 
The papers in this volume were part of the technical conference cited on the cover and title page. Papers were selected and subject to review by the editors and conference program committee. Some conference presentations may not be available for publication. Additional papers and presentation recordings may be available online in the SPIE Digital Library at SPIEDigitallibrary.org.

The papers reflect the work and thoughts of the authors and are published herein as submitted. The publisher is not responsible for the validity of the information or for any outcomes resulting from reliance thereon.

Please use the following format to cite material from these proceedings:

Author(s), "Title of Paper," in Laser Communication and Propagation through the Atmosphere and Oceans IV, edited by Alexander M. J. van Eijk, Christopher C. Davis, Stephen M. Hammel, Proceedings of SPIE Vol. 9614 (SPIE, Bellingham, WA, 2015) Six-digit Article CID Number.

ISSN: 0277-786X

ISSN: 1996-756X (electronic)

ISBN: 9781628417807

Published by

SPIE

P.O. Box 10, Bellingham, Washington 98227-0010 USA

Telephone +1 3606763290 (Pacific Time) · Fax +1 3606471445

SPIE.org

Copyright (C) 2015, Society of Photo-Optical Instrumentation Engineers.

Copying of material in this book for internal or personal use, or for the internal or personal use of specific clients, beyond the fair use provisions granted by the U.S. Copyright Law is authorized by SPIE subject to payment of copying fees. The Transactional Reporting Service base fee for this volume is $\$ 18.00$ per article (or portion thereof), which should be paid directly to the Copyright Clearance Center (CCC), 222 Rosewood Drive, Danvers, MA 01923. Payment may also be made electronically through CCC Online at copyright.com. Other copying for republication, resale, advertising or promotion, or any form of systematic or multiple reproduction of any material in this book is prohibited except with permission in writing from the publisher. The CCC fee code is 0277-786X/15/\$18.00.

Printed in the United States of America.

Publication of record for individual papers is online in the SPIE Digital Library.

\section{SPIE. DIGITAL}

Paper Numbering: Proceedings of SPIE follow an e-First publication model. A unique citation identifier (CID) number is assigned to each article at the time of publication. Utilization of CIDs allows articles to be fully citable as soon as they are published online, and connects the same identifier to all online and print versions of the publication. SPIE uses a six-digit CID article numbering system structured as follows:

- The first four digits correspond to the SPIE volume number.

- The last two digits indicate publication order within the volume using a Base 36 numbering system employing both numerals and letters. These two-number sets start with 00, 01, 02, 03, 04, $05,06,07,08,09,0 A, 0 B \ldots$ OZ, followed by 10-1Z, 20-2Z, etc. The CID Number appears on each page of the manuscript. 


\title{
Contents
}

\author{
$\checkmark$ Authors \\ vii Conference Committee
}

SESSION 1 TURBULENCE AND IMAGERY

961402 Estimation of turbulence strength, anisotropy, outer scale and spectral slope from an LED array (Invited Paper) [9614-1]

961403 Blob identification algorithms applied to laser speckle to characterize optical turbulence [9614-2]

961404 Stereo image motion monitor for atmospheric mitigation and estimation [9614-3]

961405 Imaging through turbulence using a plenoptic sensor [9614-4]

\section{SESSION 2 IMAGING IN TURBULENCE}

961407 Using aperture partitioning to improve scene recovery in horizontal long-path speckle imaging [9614-6]

961408 Efficient and physically accurate modeling and simulation of anisoplanatic imaging through the atmosphere: a space-variant volumetric image blur method [9614-7]

\section{SESSION 3 THEORY}

9614 OA Enhanced backscatter analysis for long-range optical tracking in deep turbulent conditions [9614-35]

9614 OB Spread and wander of a laser beam propagating through anisotropic furbulence [9614-10]

\section{SESSION 4 ATMOSPHERIC EFFECTS}

9614 OC Lunar laser ranging and limits due to the Earth's atmosphere [9614-11]

9614 OD Different atmospheric effects causing FSO link attenuation: experimental results and modelling in Czech Republic [9614-12] 
9614 OE Determining beam properties at an inaccessible plane using the reciprocity of atmospheric turbulence [9614-13]

9614 OF Entropy studies on beam distortion by atmospheric turbulence [9614-14]

$96140 G$ Analogue holographic wavefront sensor: a performance analysis [9614-15]

$9614 \mathrm{OH} \quad$ Infrared signature evolution of a CUBI [9614-16]

96140 An adaptive optics approach for laser beam correction in turbulence utilizing a modified plenoptic camera [9614-17]

\section{SESSION 6 NUMERICAL WEATHER PREDICTION AND ATMOSPHERIC MODELS}

$96140 \mathrm{~J}$ Estimating refractive index structure parameter $\left(C^{2} n\right)$ profiles in the atmosphere: a wavelet transform-based approach (Invited Paper) [9614-18]

9614 OK Mesoscale modeling of optical turbulence $\left(C^{2}\right)$ utilizing a novel physically based parameterization [9614-19]

9614 OL The Havemann-Taylor Fast Radiative Transfer Code (HT-FRTC) and its applications [9614-20]

$96140 \mathrm{M} \quad$ Predicting atmospheric aerosol size distributions using mixture density networks [9614-21]

\section{SESSION 7 FSO SYSTEMS}

9614 OP Optical design of communication simulator for orbital angular momentum based freespace link with an adaptive optics receiver [9614-24]

$96140 Q \quad$ Effects of vehicle exhaust to VLC link: measurement and analysis [9614-25]

POSTER SESSION

9614 OS Testing resistance modulation formats for FSO communication in turbulent environment, with used simulation box [9614-28]

9614 OT The performance of coherent receiver controlled by the phase lock loop in dual rate freespace laser communication [9614-29]

9614 OV Statistical prediction of the atmospheric behavior for free space optical link [9614-31]

9614 OX Performance analysis of OOK receiver with a GSM laser in space to ground optical communication link [9614-33]

9614 OY Orthogonal phase modulation with self homodyne detect laser communication method for the satellite-to-ground link [9614-34] 


\section{Authors}

Numbers in the index correspond to the last two digits of the six-digit citation identifier (CID) article numbering system used in Proceedings of SPIE. The first four digits reflect the volume number. Base 36 numbering is employed for the last two digits and indicates the order of articles within the volume. Numbers start with 00, 01, 02, 03, 04, 05, 06, 07, 08, 09, OA, OB...0Z, followed by 10-12, 20-2Z, etc.

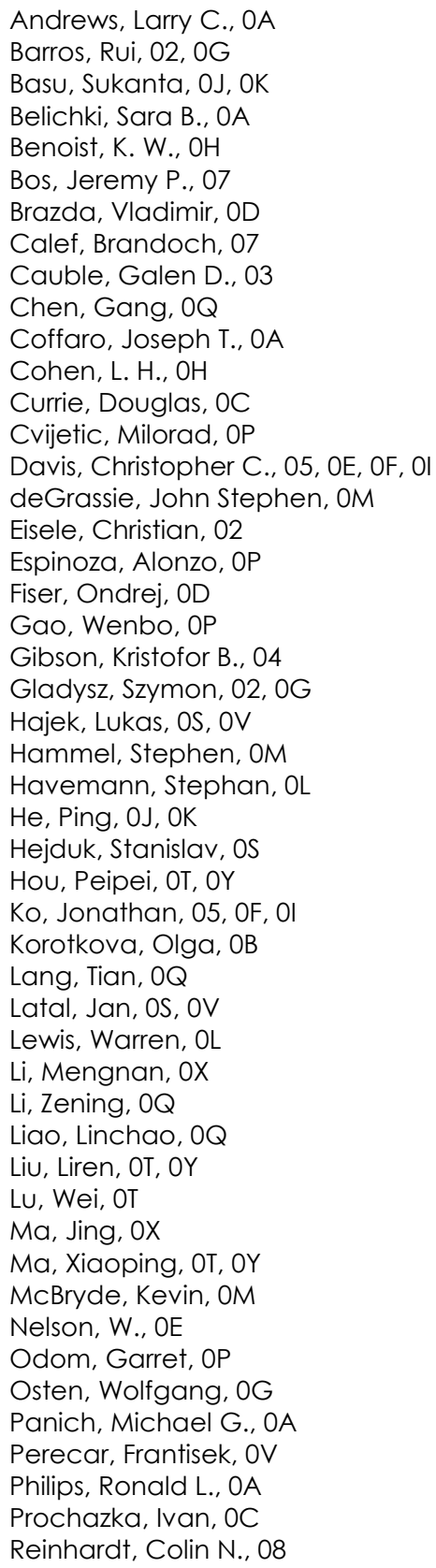

Ritcey, James A., 08

Rudiger, Joshua J., OM

Segel, Max, 02

Smith, Christopher A., OA

Splitter, Landon J., OA

Stein, Karin, OG

Sucher, Erik, 02

Sun, Jianfeng, OT, OY

Takashima, Yuzuru, OP

Tan, Liying, OX

Thelen, Jean-Claude, OL

Toselli, Italo, OB

van Eijk, A. M. J., $\mathrm{OH}$

van lersel, $M ., \mathrm{OH}$

Vanderka, Ales, OS, OV

Vasinek, Vladimir, OS, OV

Veerman, H. E. T., OH

Vitasek, Jan, OS, OV

Wang, Qi, OX

Wayne, David T., 03, OA

Wilfert, Otakar, OD

Wu, Chensheng, 05, OE, OF, Ol

Wu, Jiajie, OX

$X \cup$, Qian, OT

Yu, Siyuan, OX

Zepp, Andreas, OG 
Proc. of SPIE Vol. $9614961401-6$

Downloaded From: https://www.spiedigitallibrary.org/conference-proceedings-of-spie on 26 Apr 2023 Terms of Use: https://www.spiedigitallibrary.org/terms-of-use 


\title{
Conference Committee
}

\author{
Program Track Chairs
}

Stephen M. Hammel, Space and Naval Warfare Systems Command (United States)

Alexander M. J. van Eijk, TNO Defence, Security and Safety

(Netherlands)

\section{Conference Chairs}

Alexander M. J. van Eijk, TNO Defence, Security and Safety (Netherlands)

Christopher C. Davis, University of Maryland, College Park (United States)

Stephen M. Hammel, Space and Naval Warfare Systems Command (United States)

\section{Conference Program Committee}

Larry C. Andrews, University of Central Florida (United States) Jaime Anguita, Universidad de Los Andes (Chile)

Shlomi Arnon, Ben-Gurion University of the Negev (Israel)

Sukanta Basu, North Carolina State University (United States)

Matthew M. Bold, Lockheed Martin Space Systems Company (United States)

Jeremy P. Bos, Air Force Research Laboratory (United States)

Mikhail I. Charnotskii, National Oceanic and Atmospheric Administration (United States)

Gang Chen, University of California, Riverside (United States)

Jony Jiang Liu, U.S. Army Research Laboratory (United States)

Arun K. Majumdar, Naval Air Warfare Center Weapons Division (United States)

Vladimir B. Markov, Advanced Systems \& Technologies, Inc. (United States)

Dominic C. O'Brien, University of Oxford (United Kingdom)

Ronald L. Phillips, Florida Space Institute (United States)

William S. Rabinovich, U.S. Naval Research Laboratory (United States)

Karin Stein, Fraunhofer-Institut für Optronik, Systemtechnik und

Bildauswertung (Germany)

Miranda van lersel, TNO Defence, Security and Safety (Netherlands)

Thomas Weyrauch, University of Dayton (United States)

Otakar Wilfert, Brno University of Technology (Czech Republic)

Heba Yuksel, Bogaziçi Üniversitesi (Turkey) 


\section{Session Chairs}

1 Turbulence and Imagery

Christopher C. Davis, University of Maryland, College Park (United States)

Jeremy P. Bos, Air Force Research Laboratory (United States)

2 Imaging in Turbulence

Alexander M. J. van Eijk, TNO Defence, Security and Safety (Netherlands)

Chensheng Wu, University of Maryland, College Park (United States)

3 Theory

Miranda van lersel, TNO Defence, Security and Safety (Netherlands)

$4 \quad$ Atmospheric Effects

Miranda van lersel, TNO Defence, Security and Safety (Netherlands)

5 Turbulence Effects

Stephen M. Hammel, Space and Naval Warfare Systems Command (United States)

Mikhail I. Charnotskii, National Oceanic and Atmospheric Administration (United States)

6 Numerical Weather Prediction and Atmospheric Models

Miranda van lersel, TNO Defence, Security and Safety (Netherlands)

7 FSO Systems

John S. deGrassie, Space and Naval Warfare Systems Center Pacific (United States)

Stephen M. Hammel, Space and Naval Warfare Systems Command (United States) 